\title{
Technologies of Communication and Mass Media and Internautic Inequalities in Côte D'Ivoire
}

\author{
Joachim Diamoi Agbroffi \\ Department of Anthropology and Sociology, Alassane Ouattara University of Bouake, Côte d'Ivoire
}

Copyright $\bigcirc 2016$ by authors, all rights reserved. Authors agree that this article remains permanently open access under the terms of the Creative Commons Attribution License 4.0 International License

\begin{abstract}
The major problem being considered in this article is that of: network materials weakness and old. Inaccessibility of network. Lack of network between two antennas linked to antenna range weakness. Communicational informational and net surfer network power encompass between 2 and $3 \mathrm{G}$ while those of internet pen drive and other apparatus of net surfer navigation largely exceed them and are included between 3.75 and $4 \mathrm{G}$ (February 2016). All start with presses: monopoly state radio and television decided in 1990, but unequally split, and media and electric networks exclusively in capital and chief town of department then spread, but frequent and long perturbations, sources of unfinished and non-respect of users rights. Enclosed areas, non-electrified agglomerations and spaces without networks exist. At the level of phones, non-consumed credits after the deadline are withdrawn without being restituted to purchasers although dysfunctions and rights to dispose imperishable acquired foodstuffs exist. Ivorian radio television license free added to each electricity tax without being destined to purchasers to movies realizations nor to purchase of cultural scientific documentaries while well-off buy parabolic antennae. Illiterates, $52 \%$ of Ivorians have a program less than 10 minutes a week in local languages, well-read, $48 \%$ have their programs more 21 hours a day broadcast in French. The article is a work of socio-politic anthropologist of field. Its objective is to analyze inequalities, its thesis is to reveal the lack of media electric coverage of networks and bound inequalities remain, even if under others forms; eventually, its methods and materials, mobilized socio-anthropologic techniques and methods to collect and analyze data.
\end{abstract}

Keywords Technologies, Communication, Inequalities, Inventory of Fixture, Coverage, Radio, Television, Written Press, State, Private, Informational, Cultured

\section{Introduction}

This article treats problems other than the lack of disturbing of electrical lines, internautic communicational, and informational which are hidden. It starts by enumerating radios, written press and television in Côte d'Ivoire. It gives the occasion to see a multiplicity of inequalities in country coverage of electricity and information and communication. And, it takes these solutions particularly the established balances and makes evidence new inequalities of which no one ever dreams, and these are not to be neglected. It positions itself at the level of the media in relation to their objective: "to inform, to form and to educate", puts a particular accent on new unsuspected inequalities, and of which are already manifest and more dangerous than the first one. Always at this second level, it confronts media objectives to anterior society media with others to reveal other types of inequalities. Globally, this article presents the opportunity to see further inequalities (some are suspected and others are not) which are not to be neglected. It indicates a heuristic approach applied to inequalities linked to media.

This approach clarifies that inequalities are not always a handicap. They are welcome (because signs of culture existence, erudition, detailed knowledge, analyticity in the area where they are manifest) as communication can constitute important drawbacks (in that where they tend to disappear, but creating informational beings, increasing underlying their number while that of cultured persons decreases dizzily). Then media coverage balance reveals the existence and the growing up of informational beings and the rare persons with detailed knowledge and great analytical capacity.

Yet proposed programs which are majority made up by debates on some themes of typicality, culture, economy, politics and society. They reveal some effects of balance loss, inequality. However these programs require intellectual qualities that media in their evolution seems to fight by their informational trend which do not favour erudition, cultivated character, detailed knowledge; nor offer high level of analyticity. Contradictions of this kind are numerous in this area. For instance, $52 \%$ of illiterates to whom these programs in local languages are destined in few minutes a week while literates have enough at the level of news, who at the end, become informational persons. Mobile phones 
societies propose some devices of great capacities receptors while antenna of networks possess capacities more inferior and have little range.

The article does not set one's heart on wearing out all form of inequalities and unbalances in coverage; but signals their manifest and numerous existences. It does it so that freedom of opinion and expression (Milton, 1644) and the government of people by people for people (democracy). Which is close to the heart of specialists of communication does not undergo their impacts.

Firstly, the aim of this study is to analyze in order to decompose into inequalities in the existence and the lack of electricity, news and communication networks coverage in the evolution of all these networks and particularly in those of tic as old as new. Secondly and finally, to show that they remain under other forms. Some of them can be cited: power cut, low and high untimely tensions and frequent breakdowns of plugged devices; numerous and frequent perturbations to show bound inequalities, namely in the domain of tic and new tic. Some localities, towns, and zones are totally covered; some are not enough covered or even enclosed and without network. Illiterates, 52\% have $10 \mathrm{~min}$ per week for their programs while that of well-read is 21 hours by day. The assigned time per week bears witness to a real inequality. According to national and technical education ministry, this illiteracy average lowers to $44.7 \%$.

The defended thesis is the following: the lack and inequalities bound to tic and new tic remain again under other forms. Socio-anthropological techniques and methods were used to collect and analyze data.

The interest of the study is to show that the coverage of territorial stretch in electricity and information and communication networks is an unsuspected source of inequalities. Its originality is to show inequalities first time in Côte d'Ivoire where everybody saw networks problems.

\section{Study's Originality and Orientation}

The originality of this article is revealed by the fact that it has shown for the first time (from October $26^{\text {th }} 1962$ up date), where people talked about network and electricity problems of communication and information enumerated through the points below: problems which are not related to coverage but to network materials weakness and old. Inaccessibility of network within the same area where there is network for those who are near an antennae whereas for people who are far, network is not. Lack of network between two antennas linked to antenna range weakness. Communicational informational and net surfer network power encompass between 2 and $3 \mathrm{G}$ while those of internet pen drive and other apparatus of net surfer navigation largely exceed them and are included between 3.75 and 4G (February 2016).

People under antenna set on the roofs of their houses or living around network antenna are more beneficiary of network and more exposed to waves that impacts on health are not absolutely neuter. Those who are far from these antenna and have disagreements in matter of network are not totally exempt from waves' impacts on health. At the beginning of mobile telephony in Côte d'Ivoire, non-used credits in the assigned delay are withdrawn without restitution to customers and reserved to multiple network weaknesses. Frequent power-cut during dry seasons and many low and high voltages which damage office and household apparatus without possible realization of complains for compensation damage and interest.

Geographic raising of informational beings relative to media which inform more than they form and educate; drastic decreasing of cultured beings consecutive to what precedes: there is inequality at the level of time between illiterates and illiterates.

Licence fee destined to national movies production and purchases of documentaries are not sufficiently used to this end. Many customers who use electricity, mobile telephony, telephone, mobile telephone, internet to formulate problems that they encounter do not all received calmly response all their request. The bonus offered to incite customers for more consummation is retained without any possible restitution to the customers. Instead, according to law, any gift allocated to any client must never be retained to the giver. However, a proverb states well "given is given". Connections problems remain in matter of efficient materials and slowness of customers' communication materials. The article abandons the field of electricity and telecommunication network coverage to focus on a new field which brings out real life problems for users.

It comes out that many problems are hidden by electricity, communication and information network coverage. It is worthy to analyse, this analysis begins with an inventory of fixture.

\section{Technologies of Modern Communication: Inventory of Fixtures and Inequalities}

\section{A. At the National Scale \\ 1. Electricity and new technologies of information and communication}

New technologies of information and communication are preceded by electricity, succinctly, the problem of electricity will be tackled with that of new tic. The coverage of territorial stretch in electricity is not yet finished. Yet "les équipements existant sont vieillissants, manquent et ne peuvent pas répondre aux besoins réels" [the existing equipment are ageing, lack and cannot respond to real needs] said Tang Welbin, ambassador of china popular republic in Côte d'Ivoire in an ivoirian daily L'inter number 15308 published in 17th 122015 during the signature of the contract for the development and electric network renovation of Côte d'Ivoire. The finance of both operations 
is estimated to 427 billion CFA Franc: 853605329 millions USD dollars. The concerned number of transformation posts is $27 ; 13$ of them are new ones to be built and 14 posts need to be renovated. The number of kilometer energies transport lines on the set of the territory is 1950 for a rural electrification of 500 localities. Operations will be realized during 36 months from the contract signature date. They will end at December $15^{\text {th }}$ 2018. Meanwhile, concerned populations figure in good place among those hit by inequalities bound at once by electricity and new tic.

Thermal Central of Azito inaugurated at the end of June 2015 has a power of $430 \mathrm{MW}$ increases $10 \%$ at electricity production. The phase 3 which had allowed this result is in its conception and supply the deed of Hyundai Engineering and Construction Co LTD. It represents one-fourth of the capacity of electricity production in Côte d'Ivoire. Whatever the level where one can be, electricity product makes progress by remaining a problem.

These recent realizations are added to old ones which follow:

Six (6) dams;

Three (3) power stations;

Three (3) modes of raw productions: 1) hydro-electric production with the dams of: Ayamé1, Ayamé2, Kossou, Taabo, Buyo, and Fayé; 2) thermal production: power station of Vridi1, Ciprel and Azito, and 3) production by isolated power station (N'gbo, 2010:6). These realizations are part of Ivorian company of electricity (CIE) of Côte d'Ivoire: "l'un des réseaux de transport électriciques les plus denses et les plus fournis en Afrique occidentale". [One of the electric transport of network the densest and the thickest in West Africa]. (N'gbo, 2010: 6) without these unequal problems existing under other forms.

\section{Inventory of Fixtures of Dailies, Magazines, and Inequalities in news and communication}

From 1960 to 1990, Côte d'Ivoire has had two dailies (Fraternité Matin and Ivoir' Soir) and three magazines (Fraternité Hebdo, journal of Parti Democratique de Côte d'Ivoire (PDCI), and Ivoire dimanche). (Guillaneuf, 1975) the head offices and publishers of these dailies and magazines were all in Abidjan. Populations did not receive them neither at the same time nor the same day. For those living in enclosed areas, dailies and magazines reached them once a week, and during some bad periods hardly once month. At the very beginning, the only newspapers with large pages in Côte d'Ivoire was Fraternité Matin. At that time, the opposition was restricted, by irony some persons called it "Fraternité Menteurs".

Since 1990, date of the return to several political parties (Loukou 1985), interrupted in 1960 and veritably put an end after the conspiracy of "chat noir" of 1963, the number of dailies, magazines and other newspapers have been multiplied so much that the idea of a proliferation was not exaggerated. Now more than fifty (50) newspapers exist including the firsts (Ministry of Post Office and
Technologies of Information and Communication). They are: l'Agora, Allo Police, Bolkotch, le Democrate, Déclic,Douze, le Canal d'Abidjan, l'Eléphant Déchainé, l'Evènement, Femme d'Afrique, Fraternité Matin, Flash Afrik, le Front, Gbich, Guido, l'Initié, l'Inter, l'Intelligent d'Abidjan, Ivoir' Soir, LG Infos, Le Jour, Le Libéral, Life la Martiale, Le Matin d'Abidjan, Média Mag, Mimosas, Mousso, Le National, Le Nouvel, La Nouvelle République, Le Nouvel Réveil, Nord-Sud, Notre Voie, Le Patriote, Prestige Magasine, Le Républicain, Le Temps, Top Visages, Le Sauveur, Soir Info, Spécial Auto, Le Sport, and 24 heures. Some changed their denominations: La Voie, Le Réveil. Written press inventory of fixtures needs to be done.

\section{Inventory of Fixtures of Radios and Inequalities in News and communication.}

From 1960 to 1990 , only one national radio existed. It hardly covered all the territory of Côte d'Ivoire so much that villages near boundaries listened to the radio of bordering countries. It was not at every moment that the frequency was available. Inequalities in news were great. Unofficially, news coming from transporters, travelers, civil servants, some persons owing fix telephone and / or receiving a telegram, was that to which everyone contented with, waiting for another more recent and credible information.

After, the country opened a second radio station. The first is radio Côte d'Ivoire which broadcasts national and international news. This radio is more generalist. The second is called Fréquence 2; it is also a generalist, but specifically focused on culture and entertainment.

From 1990, many radios stations transmitted in frequency modulation (FM). According to Mahore (1969) seven categories can be counted. There are: commercial private, confessional, academic, state, foreign, institutional, and rural.

Among them, local radios transmit within a radius of 10 $\mathrm{km}$. Local, cultural and social interests dominate their news. Fifty-two (52) closeness radios can be listed on the Ivorian territory. In the only economical capital of the country, Abidjan, there exists more than ten. There are: Radio Abidjan 1, in the past called RFS, Abidjan.net FM, Radio Alobhé Bingerville, 100.8 FM (council radio), Radio Amitié, Radio Anyama, Radio ATM Port-Bouët (council radio), City FM (private legal entity), Radio Cocody (private legal entity), Radio Espoir, Radio Yopougon (Council radio), Zenith FM, and Radio N'gowa. None of these radio stations was authorized to broadcast commercial break messages. Two new radio stations: Radio Nostalgie and JAM. FM benefit from this advantage. They have been set apart from the enumeration done above. As things have been clarified, Abidjan, capital of Côte d'Ivoire has now a dozen of radios.

Among foreign radios, three transmit in FM: Africa $\mathrm{n}$ 1, BBC (Abidjan), and RFI (Abidjan Bouaké and Korhogo). The following radio was no longer authorized to broadcast commercial break messages: Voice of America (VOA) in another band. Afterwards, it was envisaged to do it on FM. 
Radio Côte d'Ivoire and Fréquence2 have a complete territorial coverage since 1990 . They transmit a full 24 hours a day. Music occupies an important place in their programs. News of these radios are synchronized from 6 AM to 8 AM. After this period, programs differ according to the target population.

The target public, the most designed is the youth (from 15 to 35 years). Those who are less than 15 years are designated by television. For the young public of the radio, programs are made up essentially with magazines and music. For those who are old than 35 years, programs are predominantly, composed of debates focusing on topicality, culture, economy, politics and society.

The target criterion of population exists. It is literacy and illiteracy. It is an important criterion. Fifty-two percent (52\%) of Ivorian population are illiterate. Some programs are broadcast in local languages; but the assigned time is few minutes a week. Other criteria have been retained, such as the notion of a stranger. Actually, there are many strangers in Côte d'Ivoire. They represent $26 \%$ of the population. Non-Africans have access to all programs broadcast in official language: French. As for Africans due to illiteracy which characterizes them, another choice of language have to be made. It is a matter of number. That of the Mossi of Burkina Faso living in Côte d'Ivoire is particularly high. So few minutes programs are consecrated to them in national language: More.

We come back to Ivorian illiterates, Touré (1984) related to inequality in time accorded during radio intervention concerning all the categories of the population. In this realm, an inequality exists between their aerial time and that of literate. If that inequality had been less important, national language programs would constitute on one hand, a latecomer mechanism of increasing ignorance in traditional cultures and civilizations, on the other hand an occasion of many young city dwellers formation that are illiterate in the language of their ethnic groups. The result is that these traditional cultures and civilisations do not present advantage in the development of country. If they present an ordinary language by which they (culture and civilization) are acquired, they would have been important in the balance of aerial time. Illiteracy is seen as an obstacle even a handicap, and not as a culture, a national source of cultures, of local knowledge to be preserved through perpetuation. Illiteracy and literacy constitute a same line of demarcation between two cultures: occident Europe and traditional. It is not only a matter of incapacity of one group to express itself in the language of another and vice versa. This is not at present understood, time assigned to national language programs is destined unilateral to the translation of the messages in French. What a pity for media which slogan is to inform, to form and to educate!

Concerning radio broadcastings in French, the problem which is faced, in the first instance, is inequality. It is matter to satisfy a logic of software which must dominate all. However, official language should not be sufficient for itself. It is made up of numerous and cultural borrowings. Yet its languages and cultures supply and / or traditional civilizations and its relating culture are not veritably the object of major preoccupation in arena's time. The cultural level of these messages is surely low and if not all essentially informational in order. The analytical deepening that the excess lead to the invisible in traditional cultures is not exploited. The same deepening which in the official language made science more dominant is no longer taken into account in news as such that the informational character is surely dominant and determines behaviours. All responsibility in this situation cannot be assumed by media only. Two essential reasons are to be evoked.

The first is that in social representation of the Ivorian, a book is in schools, university and for professional interest. The one who has given studies up; has almost abandons books. So it is totally absent in the life of those who are no longer in formation namely workers, jobless and retired. The conception which is made of a book; rooted man on the shelf and offering diverse possibilities of exchange at all moment is very rare in Côte d'Ivoire. The one who conceives it as an opinion, a section of culture, of civilisation and its author, adviser immortalized is equally all exceptional. If these two conceptions with many contents were understood by the majority of the population, even illiterates would be able to read and write. Lack of culture daily life of lot of Ivorian is a deep problem grounded since a long time.

In the principle of ordinary modern house building, not all compartment of the house are destined to the same activity such as the bathroom, the kitchen, dining room and toilet are for the service of stomach. There is no place in term of economical level for cultural interest. In the past; the nocturnal continuity of domestic, rural, hunting, aquatic activities were not included in the traditional room. The main interest of a house and its composition of rooms with beds and many mats on which many children are destined to sleep is the same as the bed of the parents. There is no extra space for those academic and bureaucratic workers who wish to do some of their works at home and seem to penalize because there are no room extra to permit them to continue the extra work at home.

Library and table of study are useful for pupils, students and parents which gives way to any countable room in the ordinary which required to obtain planning permission in Côte d'Ivoire is to be reformulated. At present, stationery shops seem to be more important and thicker than bookshops that the number is considerably decreasing as diminishing asset. In old days where fifty thousand (50000) French members of the Peace Corps lived in Côte d'Ivoire, bookshops were numerous and thick. Secondary schools and colleges bookshops have been cancelled at certain moment. Even in universities libraries do not recommend veritably themselves by the important number of their varied resources neither by the novelty of their stock nor by the destined budget for the documentation purchase is entirely hiked at the end. All this is highly seen in news. If it was a time, namely that of colonial and post-colonial, precisely person doing voluntary service overseas where words were 
punctuated of quotes from reading, today they are almost inexistent at national's and rare at oral and even theoretical writings. From what precedes, news results neither from fieldwork nor from exploitation of documentary data analytically detailed.

At the end, it is like informational man not cultured one that most persons intervene. Some specialist exists but there are rarely search for their knowledge. The passionate of data reality who have cultural exceptional scope generally exist, but often they do not enough programs.

The second reason is that Ivorian does not dissociate language from culture and verse versa. Yet there are both distinct. Language is made up of alphabet letters and rules that the acquisition allows ideation, application of the invisible world to the material and to the immaterial in order to form and link ideas, to test what was felt, imagine, and create usage of his reflection and express thoughts. Culture results from development of certain spiritual faculties through some suitable discerning intellectual exercises which successful realization is the set of intellectual aspects of a person and / or of a civilisation that are their knowledge, acquaintances, specific gain perpetually enriched and analytically detailed. The news supplies resulting from faithful memory, some innovations, inventions worth of interests are decisive. Culture is a result of a manifest unquenchable thirst. The set of these result characterized by erudition does not dominate neither in news nor in debates. Many participants focus themselves on non-analytically detailed received news to inform. They transmit them to other in the best cases, as they received them and in the worst cases partially or totally modified. Participants count more or less on mastering of French language than culture. However analytical deepening exists in news and communication.

Rapidity of news would not justify its superficial character of the media data and what can be informational instead of cultivated, erudite. Inequalities are already great in the relation informational being/ cultured man, in the frame of media slogan is "to inform, to form and to educate". Yet radio stations are insufficient in number.

Radios that have more listeners than another technology of news have not enough stations. In term of radio stations, global list exists. It puts forward what follows: Abidjan.net, Bengueshow, City FM, Cocody FM,Frequence2, Nostalgie CI, ONUCI FM, Radio Abidjan 1, Radio Alobhé Bingerville FM, Radio Amitié, Radio Anyama; Radio ATM, Radio Côte d'Ivoire, Radio JAM, Radio Espoir, RFI, RFI 1 Afrique, Radio Fréquence vie (evangelic church radio of Côte d'Ivoire), Radio Man (catholic), Radio Nationale Catholique (la voix de l'évangile), in Bouaké, Radio Nationale Islamique "Radio Al bayane", Radio Notre Dame (Yamoussoukro), Radio Paix Sanwi; (Aboisso), Radio phenix (Bouaké), Radio Yopougon, and Zénith FM. Although the number of these radios continues to increase, the aforesaid media are more in the town of Abidjan than in others. An inequality comes out again in the country.

\section{Inventory of Fixtures of Television and Inequality in News and communication}

Ivorian television is added to newspapers and radio in October $26^{\text {th }} 1962$. Côte d'Ivoire had her radio television ivoirienne in short RTI. In details, she gives right to two channels of televisions: Radio Télévision Ivoirienne 1 and 2 respectively in abbreviated form RTI1 and RTI2, to which is added a third regional based in Bouaké at the centre of the country.

RTI1 transmits messages of government during the week on a radius of $100 \mathrm{~km}$ in surroundings of Abidjan. Beyond this limit, program is done through relay stations. Abidjan is the centre of all transmittions: (Abobo and Cocody), and others Bouaké, Dabakala, Divo, Dimbokro, Koun-Fao, Man, Niangbo, Niangué, Séguéla, Tiéné and Touba.

All these transmittions have been recently changed for a program of quality, and of a greater scope. Other cities do not possess transmitters and done renovations do not totally satisfy the need as regard to program and news reception. Inequalities in expressing opinion and listening remained. The average of hours of RTI1 daily programs is situated between $10 \mathrm{am}$ to $1 \mathrm{pm}$; those of RTI2 between $6 \mathrm{am}$ to $8 \mathrm{am}$. Another great inequality is revealed here.

Since the return to many parties in 1990, there is a diversity of local radios, televisions and a proliferation of private newspapers. To the old stations, are added some new radio stations in the following towns: Bonoua, Bouaké, Bécouéfin, Grand-Lahou, Grabo, Kong, Kouakoussekro, Maféré, M'Bengué, Taï, Tehini, Tingrela, Touleupleu and Zoukougbeu.

It will be a matter of indicating the set of impacts that the media have exerted on society update and vice versa. Before the event of many political parties, it was state media services that transmitted news to the populations. The reverse was neither very obvious nor easy. During the war from 2002 to 2010, northern people were deprived from all programs for five years, from 2002 to 2007, except the breaking news of the first channel of television "RTI1" from which they receive news, it was not really watched because state transmitted channel was called as false and non-liked in relation to foreign.

Youth did not wait for long time to react against state media. From 2003 to 2008, in January 2006 during the period in which there was neither war nor peace patriotic youth, stemming from militia and trained invested RTI. In such situations, menaces were accentuated. The staff have received some threats. However, there was no confrontation neither between staff and young patriots nor between them and security contingent came for reinforcement.

From one side, the act is accepted, but deplored on the other side as it is the case at the lively tensions. NGO's that intervene at that period, UN contingents and media noticed the reason of these reactions and the fact to disturb during a certain time programs and freedom of expression. From both sides, even if someone disagrees with another, he may let him express freely himself. Jamming and restriction of 
programs and intimidations were some of mechanisms which restricted freedom of expression. Skilfully orchestrated lie is a crime, that is why Milton in Aeropage wrote that:"tuer la pensée est plus criminal que l'assassinat materiel d'un homme" (1644:148). The network problem particularly important and rarity of media on a given territory constitute real difficulties in matter of intellectual blossoming, necessary to freedom of expression in best conditions.

\section{B. At the International Scale}

On the international level, two situations are detected: that of Ivoirians who live abroad and their guests. News that the country possess about herself and that it transmits to its nationals abroad and their guests, and this that foreign countries are in possession about Côte d'Ivoire and transmit to their populations and to strangers were contradictory and partisan. Frequent jamming, and network problems are precarious attempts of solution. Impartiality and objectivity are radical solution of that kind of news program and which soils the scientific dimension of the discipline and professional ethics. They are necessary for the balance of news and media contribution to stability to state peace.

The internationalization of Radio Côte d'Ivoire, Fréquence2, Radio Télévision Ivoirienne 1 "RTI1" is seen as another solution. Their programs are broadcast on Canalsat Horizons. Therefore, they are available in the world through satellite and cable for those who got Canalsat subscription. Through internet, channels are also available in live broadcast in the world and on the official site of RTI group: www.rti.ci. Concerning newspapers, the site is the following: www.abidjan.net. Two major problems are at stake. Informatics materials, have a capacity of $3 \mathrm{G} 75$, instead, the power of the antenna are by order $2 \mathrm{G}$ in some areas. This difference is detrimental to customers. Difficulties to have network are real in the country. Despites their impact on human health which is not totally clear-cut without playing their role, aerials with weak radiation exist everywhere ignoring the reason for why they were implanted.

The fact that technologies of communication are available in a given territory is not a sign for news to be balanced. Abroad, programs jamming are possible. Lasting solution is found in objectivity, impartiality, respect of ethics code, freedom of expression and in democracy. Inequalities are complex and profound.

At the international scale, at the beginning, it was the radio of colonial countries. To this international radio were added many others of the same nature among them, we can cite: BBC, VOA, and sometimes foreign television channels. News plurality is salutary but sometimes it can create confusion which deserves an exam at a general level.

\section{General and Compared Exams}

During the wars where developed countries intervene, most of the time, journalists are incorporated in the state army and that of allies to cover the events. For this end, journalists of opposition and all those against the war are exempted. Another inequality in communication is found on that level. It is the censorship of the opposition and participation of all against the war. It was the reforming of Journalists on the side of peace who refuse to the coverage of the event. Formation of Journalists with objective as warriors could be organized. Reaction against all these things manifests itself by attacks of journalists, for they cannot work neither freely nor freedom in expression. The discriminatory situation at a high level can be the origin of ardour capable to provoke some reactions of appearances against freedom of expression but which in reality are totally true. Then it is neither the case of what under the absolute dependence of someone, nor what he does not undergo constraint, nor the case of someone who is not linked to commitment, nor the power to act in the limits of society current rules, nor the power that law recognizes to individuals in some precise domain, nor what is fulfilled freely which directly attacked, combated, but passion acts somewhat instinctual. All these are some means of inequalities of diverse forms. What happens in Côte d'Ivoire?

\section{A. Situation of Côte d'Ivoire during the Two Wars}

In Côte d'Ivoire, at the beginning, in rebels' zone, war was partially covered directly by national journalists and those of foreign media in favour of the rebels. True images showing rebels in difficulty were never broadcast in all news given. It was the same in that of state media. Citizens whose local taxes are used to finance the army and the war have no right to correct news. Encountered difficulties are hidden by the army from the population which supply everything. On both sides, this kind of reserve, mystery in matter of news has been pushed so far that everything was considered as a lie. Consequently, images and other information supplied were those of party against another.

Actually, war coverage in Côte d'Ivoire by media did not work correctly. Militaries, soldiers, and policemen were disorganized. Some stay the group to which they belong, others that of rebels. True alliances were considered as obtained for a given camp against another existed, sometimes without foundation. Battles, actions of both armies which were fighting did not take place. Everywhere attacks have been many. From one side, they sustained organization for fighting, on the other side there was combated and condemned organization.

For all these reasons, media did not act effectively to cover the events. National media worked out of occasional battle field and areas of sporadic attacks. Therefore, imperfection, difficulties and exactions and the violation of war prescriptions took really from one side and another, and have not been subject of real news. That received by southern and abroad populations concerning conflict, armed conflict and war were respectively that of southern and foreign media. Many Ivorian have long time been without true information. Inequalities in real news have particularly been great. 
In addition, government reacted against news which were unfavourable for him, by jamming western media namely RFI in Côte d'Ivoire without doing so in world wild. The state does nothing against what deprived the population from foreign news. This situation has been used against Ivorian state, sometimes what happened on her territory are amplified through imagination. The insufficiency, banking, and lack of news were particularly complex.

Foreign media influences wanted to exert upon Ivorian society and the world, and that of national media in return wanted to exert on the south of Côte d'Ivoire and the world. These news are not most of the time presented as objective data and scientifically verified by the person who wishes to know. From one side as other, the manifested intention to deceive, to hide reality, to present a situation more seriously which was not reality. For all these reasons, inequalities were several. Reparation on reliable objective and verifiable basis of justice and of faults caused in much more conflict and wars were not easy. Inequalities in news can then be potential sources of instability. Self-overtaking and truth searching are indispensable.

In Côte d'Ivoire, some journalists recognized that they had a part of responsibility in the conflicts, armed conflicts, and wars. They have been among dissension and scourge actors. Always in this country, during an organized conference in Bouaké, other journalists recognized that they were not free to write and publish what they thought. They wrote what the party to which their newspaper affiliated wanted seeing published or announced. Elsewhere a text from a journalist and other one sometimes modified without the agreement of their authors.

Le courier d'Abidjan, chief editor Théophile KOUAMOUO said how he resigned after the publication of an article in the newspaper "Le Monde" to which he belonged and in which he did not recognize himself at all. For, he has been made author of an article that he was not the real author. He created his own newspaper that headquarter is seated at Rivera Bonoumin, near college André Malreaux.

\section{B. Consequences: Advantages and Drawbacks}

To make disappear some personalities from public or private scene; (Thibau, 1973) the most wanted are media workers (civil servants). Such preoccupation leads to deplorable situation. Partiality had been manifested at a given time. Some trials of defamation have been engaged against certain journalists or against some press and have been won. Investigation journalism which set its nose everywhere has been the genre, the style of certain newspapers. Some journalists have been pulled more or less by an unhealthy curiosity .Private, public and political lives have been confused some excess of ardour in investigation practice, investigation journalism, investigation took place. Hate, mistrust, prejudices, and tensions have been showed through. Some news which readers possess are different from that of auditors. Eagerness to discover the secret leads to error. For, these press civil servants consider themselves as great investigators and happy have affected their profession. Journalist development and promotion can be responsible of situation evoked above. The rise of tension between press and power or the actual government have multiples causes. The set of situations leads some media to be seen as menaces of disorder for society. All this has set a mistrust regarding media civil servant. In such context the bugging of phones of certain persons increased. Does not exist the work done for social ascension, of a celebrity who hinders ethics code or who gets used to stardom, to the glory on the fall of public and private men which inspire to resign, to exaggerate the muckraking "revelation of scandal, muckraker, scandal denunciation". These situations aggravated inequalities in news. Be informed without these situations and to have reliable news have been urgent needs.

\section{To Be Informed Is to Possess Reliable News}

The principle according to which to be informed is to have reliable news, is applying more and more difficultly. News destined to the whole society is done to the detriment of current news reliability. The fact of being the first to be informed worries more that its reliability. Objectivity, reliability, verifiability and in one word scientific character are less worthy than the fact that to be the first to give news about an event. This situation is particularly serious in developing countries since the coming of new technologies of information. The worst, elsewhere where media do not sufficiently constitute a mean of popularisation of scientific results do not associate for each reality some renowned speciality or of cultural appreciable scope. At this level, inequalities in objectivity are particularly great. The unbalance in news is a veritable obstacle to development. To equal intelligence, the one who has reliable news surely succeed more than the other who does not. Disproportion in reliable knowledge is an important criterion of development. Elsewhere, countries which have used formation as a mean of their success have more decisive advances in development than those of which have neglected it. Inequalities in news scientific and technologic constitute an important indicator of classifying rich and poor countries. The interval between both, really holds under glaring and spectacularly advances in training, education and news.

Media do not inform its populations taking into account many considerations certain set of aspects of reality. Culture is widespread. All information constitutes an important mean for its acquisition. However, emotional reaction constitutes the essential of news, and if not the most important part, leads to inequalities in communication. The fracas and the emotional do a real harm to the receptors, populations in matter of acquisition of knowledge. Actually the more a man sees more scandals, hear speaking around himself, reads documents which essentially contain and/or particularly aim them and in other words to be informed, the more he is drawn, and he is interested, likes to be part of his life and has little means of latecomer to prevent him to commit crime. On this basis, media productions constitute 
some favour of accelerator of scandals and sensations (McCarthy 1974), some dispositions and even some pre-required for their proliferation. On this basis, from one side inequalities in news are deplorable, but on the other side, analytically detailed salutary because shelter some scandals, sensational story from their consequences and conserving the old knowledge defined by dictionaries as "erudition, detailed knowledge based on study of historical sources, documents, texts". At this level, inequalities hide a cultural drop: informational and cultural. There is a culture of informational by opposition to culture in the sense of erudition before the event of media. In this case, the lack and insufficiency of news which generate inequalities that preserve from lack of culture, erudition, in that case, obstacle is an expression of informational and godsend of erudition. Inequalities are expression of complex realities.

Objectivity, verifiability, reliability and scientific character which do not constitute the essential of media preoccupation and specially the aim of media productions make lose to media their weight in culture and erudition. Inequalities put man in a horrifying situation because of imponderability of their mass of simple news. The news content weakly based on scientific character creating less eagerness at the detailed analysis and excessively focused on scandals and sensations is one of the fundamental causes which lead passionate of news to be informational and not cultivated. In this manner, culture of mass leads to become informational. From what precedes, informational citizen deserves a clarification.

\section{Informational Citizen}

Informational citizen (Lasswell, 1976; Lazarsfeld, 1940 and 1948; Wright, 1973; Mattelart, 2004) is a citizen whose knowledge is composed of: cataclysm "political scandals, war, guerrilla warfare, and conflict", natural disasters "flood, earthquake, famine, dryness, epidemic", and fresh outbreak of criminality. His knowledge is full of painful memories, dangerous events: accident victims, mutilated, mourning, violence, conflicts, armed conflicts, and wars. He is a being that his curiosity is focused on scandals, disasters, absence of peace. He is draw by misfortune; he sought and ended by reproducing these events. He is scandal conflict violence man. Then, he is insensitive. His sensitivity is weak in matter of detailed analyticity. He is inclined to an aggression, a rape, a fight only motivated by the fact to be the first to be informed and the first to relate the event. Media informational character makes dehumanized disintegrated dissocialized men without knowing what he is. For some futilities he becomes talkative, and reduced to silence when it is a matter of coming out of scandal, violence, conflicts, armed conflicts, wars and calamities sphere to reflect and think profoundly. He becomes nervous, violent, aggressive, intolerant, and insensitive whereas, another person mobilizes his knowledge for self-control. The cause can be the fact that he acquired an important amount of news with less training and education. These inequalities form part in situation of informational being, and that of cultivated, and erudite being needs a quick examination from cultural passage to informational in news.

\section{E. Passage from Cultural to Informational in American News}

In the beginning, (Schudson, 2001) American media had for role and ambition to give news on cultural practices that residents let on European continent. They are a faithful memory of cultural past of a continent and its people. At that epoch, they were so important that they were carefully conserved as books. Their role in the recall of memories did not be discussed. The media productions were nearly history documents.

Media ceased to broadcast news of this kind when they are interested to politics (Vautraver, 1994). If in the first case, it was population that they intended to satisfy; in the second one, it was interviewees, those selected on whom news is given. It was no longer the content which is important in news but the fact to be the first on whom news is given. Very early, offensive written texts were published to make someone else feel ill at ease with the intention to satisfy another one. The passage from cultural to informational started with multi-forms of inequalities. And it is at this moment that the objective consisting to contribute to democracy is become fundamental.

In Côte d'Ivoire, the beginnings of journalism had equally been marked by a real passion for what is analytically detailed; such as local knowledge, proverbs and dictums, modern world knowledge, good quotes, professionalism which is realized in the same perspective as the first qualities. It was an epoch where they say that "un vieillard qui meurt, c'est une bibliothèque qui brûle" (Hampâté Ba) which translated into English generates the following sentence: "an old man who dies, it is a library that burns". Then, news has started from its qualities to be composed of simple announcements of facts, of events, of lapidary news. Democracy and freedom of expression that would take pleasure in this last phase of news would change their opinions if people was neither cultured way, nor fairly nor freely the real sovereign.

\section{F. Media and Democracy}

The fact to give an objective and reliable knowledge is relegated to the second plan. It is important to wander if veritably media contribute to democracy? Democracy (Ostrogorski, 1979; Milton, 1644) essential foundation is the government of people by people for people. The government requests a knowledge peculiar to people and knowledge of universal principles of people self-government. Media worked to give more democracy, freedom to people and all citizens. However informational personality forcing to media passionate is not indicated for a best democracy practice. Considerations linked to the lack of objectivity, partiality, violation of ethics rules, and right to freedom of expression, witness that the democracy problem is not solved even within media. Often these principles seem enough ridiculed indicate that this kind of regime is not admirably practiced 
within media structures. They are indeed, particularly those who are the vassal of political parties and subject to partiality and all financially dependent to these parties or attacked for their opinions, freedom of expression and democracy are foods of impulsion of a change which implies itself nearly everywhere. Meanwhile satiety, attacks on freedom of expression are several and important. For instance, the disappearing in October $26^{\text {th }} 2004$ of Guy André Kieffer a Franco-Canadian journalist; gunfire in October $21^{\text {st }} 2004$ of Jean-Hélène French journalist killed by Ivorian policeman Theodore Seri; twice destruction of the siege of the daily "Le Patriote", and once that of "Radio Nostalgie" by a criminal act, attack of Canalsat Horizons' siege, interruptions of RFI, $\mathrm{BBC}$, and Africa $\mathrm{n} 1$ programs; also twice repeated havoc of press office, aggression of delivery men, sellers, and destruction of target dailies such as: "Le Jour Plus, Le Liberal, Le Patriote, and 24heures", aggression, analysis intimidation and kidnapping of many journalists.

\section{Recommendations}

For communication and information, companies have to increase the power of their network to reach that of communication materials which is $3 \mathrm{G} 75$ for adequacy between that of network materials and that of customers at the level of communication and information.

For electricity, government must find a solution to power-cut by increasing electricity production in the country.

Setting-up and follow up evaluation structure for materials repairs and improvement.

Proposal to set up a satellite network, for the time being, companies must seek quickly replacement of old materials.

Government must envisage to balance aerial time for local and official languages.

Media have to increase time and formational and educational means for the interest of cultivated people.

Companies have to put bonuses directly on their users' accounts and not in another parallel account.

Replacement of materials that do not respect environmental norms.

The system of exploitation need to be democratized: for example when a mobile telephony wants to implant a satellite network other companies complain.

Deletion of all accounts where bonuses are deposited in accordance to Ivoirian law must not be withdrawn.

\section{Conclusions}

In this article, we have explained that the media coverage poses a real problem in Côte d'Ivoire. A made inventory of fixture allowed to follow the resolution in time and in space. Originally, it was a matter to put an end to some inequalities in the coverage. The so wanted equality has not been obtained. A vast number of situations lead inequalities to remain always under diverse forms. The last inequalities are much more important and deep than the simple installations of relay stations. Media are concerned in their project and program of populations behaviours change. States, structures and citizens are equally concerned. Democracy (government of people, by people and for people) and freedom of expression would have interest to cease inequalities. At the international scale, the exaggerated competition which exists, obliges populations to be cultured rather than superficially informed. It imposes that the same luck must be given to all so that competitors may be more numerous and more efficient face to all adversities.

\section{REFERENCES}

[1] Agee (Warren K.), Ault (Phillip H.), Emery (Edwin), 1989, Medias, Paris, Nouveaux Horizons, 735 p.

[2] Asline (Jacques), 2008, Présentateur vedette : ce qu'on ne vous a jamais dit sur Patrick Poivre D'Arvor et les coulisses du 20 heures de TF1, Editions Alphée-Jean-Paul Bertrand, Monaco, $725 \mathrm{p}$.

[3] Bailly (Diégou) (1996, s. dir.). L'état de la presse en Côte d'Ivoire, Abidjan, SII, 143 p.

[4] Decaux (Alain), 1992, Le tapis rouge, Paris, Perrin, 433 p.

[5] Dennis (Everette E.) et Merrill (John C.), 1993, Les medias en question, Manille-Philippines, Nouveaux Horizons, 325 p.

[6] Gaudio (Attilio), Roekeghem (Patrick Van), 1984, Etonnante Côte d'Ivoire, Paris, Karthala, 266 p.

[7] Guillaneuf (Raymond) 1975, La presse en Côte d'Ivoire : La colonisation, l'aube de la décolonisation (1906-1952), Paris Université de Paris I, 2 volumes, $614 \mathrm{p}$ (Thèse de doctorat $3^{\mathrm{e}}$ cycle d'Histoire contemporaine).

[8] Henno (Jacques), 1993, La presse économique et financière, Paris, Presses universitaires France, Coll. «Que sais-je » 127 p.

[9] Klitgaard (Robert), 1999, Combattre la corruption, Nouveaux Horizons, Manille-Philippines, $227 \mathrm{p}$.

[10] Loucou (Jean-Noël), 1992, Le multipartisme en Côte d'Ivoire, Editions Neter, Abidjan, 213 p.

[11] Laramée (Alain), 2004, La communication dans les organisations : une introduction théorique et pragmatique, Télé-université, Québec, 266 p.

[12] Lasswell (Harold), 1976, Power and Personnality, Norton, Norton Library, 265p.

[13] Lazardsfeld (Paul), 1940, Radio and printed page. An introduction of study of radio and its role in the communication of ideas. New York, Duell, Sloan and Peace,

[14] Lazardsfeld (Paul), 1944, People Choice: How the Voter Makes up his mind in a presidential campaign, New York, Duell, 178 p. 
[15] Mahou (Ahmed) 1969, L'Avènement des partis politique en Afrique noire, Paris, Libraire générale de droit et de jurisprudence, 1969, $421 \mathrm{p}$.

[16] Marshall Mc Luhan, 1977, Pour comprendre les médias, Paris, Mame/Seuil, $404 \mathrm{p}$.

[17] Mattelart (Armand), 2004, Histoire des théories de la communication, Paris, La Découverte, 123 p.

[18] McCarthy (Mary), 1974, Watergate : La tragédie de l'Amérique, Gallimard, France, 199 p.

[19] Meyssan (Thierry), 2002, 11 septembre 2001 : l'effroyable imposture, Carnot, France, $235 \mathrm{p}$.

[20] Milton (John) 1644, Aréopagitique ou De la liberté de la presse et de la censure, London,

[21] Murray (Joan), 1970, Le petit écran et moi, Tours, Nouveaux Horizons, $122 \mathrm{p}$.

[22] Nacos (Brigitte L.), 2005, Medias et terrorisme: du rôle centrale des medias et le contre-terrorisme, Paris, Nouveaux Horizons, $249 \mathrm{p}$.

[23] N'GBo (AkéG.M.), 2009, «Participation du Privé à la fourniture d'eau et d'électricité en Côte d'Ivoire : Bilan et perspectives "), in Bulletin de Politique économique et developpement, $\mathrm{n}^{\mathrm{0}} 10 / 2009,13 \mathrm{p}$.

[24] Ostrogorski (Mosei) 1979, La démocratie et les partis politiques, Présentation de Pierre Rosanvallon, Paris, Le Seuil, Col. «Points politiques», $312 \mathrm{p}$.

[25] Schudson (Michael), 2001, Le pouvoirs des medias : journalisme et démocratie ; Paris, Nouveaux Horizons, 277 p.

[26] Thibau (Jacques), 1973, La télévision le pouvoir et l'argent, Paris, Calmann-Lévy, 183 p.

[27] Touré (Abdoulaye Jabali), 1984, Les bâtisseurs de l'enseignement en Côte d'Ivoire (1942-1958), Abidjan, Editions CEDA. 151 p.

[28] Vautraver (Constant), Mattalia (Alex), 1994, Des journaux et des hommes : du XVIII ${ }^{\mathrm{e}}$ au XXI $\mathrm{XX}^{\mathrm{e}}$ siècle à Marseille et en Provence, Editions A. Barthelemy, Avignon, 263 p.

[29] Wright (Charles R.), 1973, "Analyse fonctionnaliste et communication de masse", in Balle F. et Padioleau J.C. Sociologie de l'information, Paris, Larousse, pp.53-67.

[30] Ziegler (Jean), 1983, Contre l'ordre du monde: Les rebelles, Paris, Editions du Deuil, 413 p. 